\title{
Speech Act Analysis of the Dialogues in Henshaw's This Is Our Chance
}

\author{
Samaila Yakubu (Corresponding author) \\ Department of English and Literary Studies, Federal University Wukari, Taraba State, Nigeria \\ Email: samailayaku@gmail.com
}

Received: $11 / 01 / 2021$

Accepted: 20/03/2021

Published: 01/05/2021

Volume: 2 Issue: 3

How to cite this paper: Yakubu, S. (2021). Speech Act Analysis of the Dialogues in Henshaw's This Is Our Chance. Journal of Critical Studies in Language and Literature, 2(3), 20-26

DOI: https://doi.org/10.46809/jcs1l.v2i3.66

Copyright (C) 2020 by author(s) and Global Talent Academy Ltd. This work is licensed under the Creative Commons Attribution International License (CC BY 4.0).

http://creativecommons.org/licenses/by/4.0/

$$
\text { (c) (i) }
$$

\begin{abstract}
Speech act analysis is an act of investigating how utterances not only disseminate information but perform actions as well. Dialogues in Henshaw's This Is Our Chance are not only employed to exchange information about animosity between the people of Koloro Village and the people of Udura Village but to take actions on matters that involved the two neighbouring villages. The present paper seeks to explore the dialogues in the above mentioned text to see how they have been used. The paper adopts speech act theory of J. L. Austin which was later developed by J. R. Searle. The data for the study were analysed based on speech act theory. Components of directive speech act such as commands and questions are used extensively in the text while those like requests, advice, directives and warnings are used insignificantly; constituents of representative speech act, namely, statements and reports run throughout the text; elements of expressive speech act such as complaints and appreciations are found in the text; declaration speech acts, and constituent of commissive speech act such as promise are used scantly in the text. The study concludes that speech act theory is the most appropriate instrument for handling civil conflict.
\end{abstract}

Keywords: Speech Act Analysis, Dialogues, Performance, James Ene Henshaw, Illocutionary Act

\section{Introduction}

Speech act theory is a subfield of pragmatics that is employed to study how words are used not only to disseminate information but to carry out actions also. The theory was propounded by J. L Austin and further developed by J.R. Searle (Nordquist, 2020).

In How to Do Things with Words, Austin argues that instead of paying too much attention to semantics and what words stand for, we should focus on different things that people do or the act they perform when they speak (How to Do Things with Words Summary, 2020)

In speech act theory, the minimum unit of human communication is not a sentence or other expression, but the performance of certain types of acts, such as asking questions, giving orders, making statements, describing, explaining, apologizing, thanking, congratulating, etc. (Searle, Kiefer and Bierwisch, 1980). Speech act as used in philosophical tradition serves as a key to grasping language. The theory is richer than earlier tendency to think only in term of propositional truths (Ian, 2020) Traun (n.d.) asserts that the basic insight of speech act theory is not just to transmit information but to carry out action which will change the state of affairs of the participants in a conversation. He further says that if the states of affairs of the participants are changed, we see changes on the state of their minds. 
James Ene Henshaw is a Nigerian playwright of Efic tribe. He has written a number of plays which treat different aspects of African cultures and traditions. He is a physician who starts writing plays after obtaining his medical degree from National University Ireland (Encyclopedia Britannica).

In This Is Our Chance, Kudaro the princess of Koloro village is in love with Ndamu the prince of Udura village. The people of Koloro and Udura have been at enmity for many years. The custom of the people of Koloro forbids any citizen of the village to marry from Udura village and vice versa. Unfortunately, princess Kudaro elopes in order to get married to prince Ndamu; she is caught by the search party from the Udura village and puts in prison. Ndamu is also caught by the search party from Koloro village and puts in prison. While Kudaro is in prison a poisonous snake bites the younger son of the chief of the village. Attempts to revive him prove abortive until Kudaro treats him with an antidote given to her by her teacher before he recovers. This good deed makes Mboli, the chief of Udura, to release Kudaro and seeks to be at peace with the people of Koloro. King Damba agrees to Mboli's peace proposal and promises that the two neighbouring villages will shun animosity between them and marry from each other's villages (Henshaw, 2004).

Many academics and researchers have studied Henshaw's pieces of work, particularly, This Is Our Chance, from literary and linguistic aspects. To be specific, some aspects of the text have been explored through stylistics, Discourse analysis and critical Discourse analysis but no enough scholarly attention has been given to speech act analysis of the text. This study, therefore, seeks to investigate how dialogues manifest in the literary text via the following objectives:

1. To identify the dialogues in the text

2. To classify them into different speech acts

3. To discuss them in consonant with the text preoccupation.

Students on English and Literary Studies, researchers who may be interested in working on the same or similar topics, playwrights and even Poets and novelists will find the work beneficial. The study may be beneficial to the general public in the sense that they will employ dialogue in handling civil crisis as it is very effective in dealing with such a matter.

\section{Review of Related Literature}

Fadhil(2018) conducted a research on pragmatic study of speech acts in school speeches. The study aimed at finding out which of the five speech acts namely, assertives, commissives, directives and expressives were used mostly in some selected High School graduation speeches. Searle (1969) Speech act model was used to analyse the data. The paper discovered that most of the speech acts used in the graduation ceremonies were directives, they were realized via imperative sentences. Assertive speech acts were also used extensively; they were expressed through declarative sentences. The remaining speech acts such as commissives, declaratives and expressives were also employed, but they were used scantly. The study concludes that the school principals used all the five types of speech acts mentioned above in high school graduation speeches but they were not used equally.

In a similar vein, Al-Owaidi(2018) conducted a research on speech acts in English and Arabic short News interviews: A cross-cultural pragmatic study. The study aimed at investigating the speech acts used in all the interactions and the Illocutionary Force Indicating Devices (hence forth IFIDS) employed to identify speech act in an interactive context, and to compare the investigated speech acts and IFIDS cross-culturally between English and Arabic. The study investigated 12 English and Arabic Short News interviews (Six for English, six for Arabic). Some of the short news interviews were videorecorded live from the British Broadcasting Corporation (BBC), Sky News Channels, Al-Arabia, Sky-News Arabia and AlWataniya Channels while others were downloaded from YouTube. The interviews were focused on two topics namely (i) the immigration crisis in 2015 and (ii) the Iranian nuclear deal in 2015. Forty eight (48) speech acts were analyzed and the results show that different types of speech acts based on the roles they play on the discourse were identified. The first type is called turn speech act; it has a special status in the turn in which it occurs. The second type is known as interactional act; it derives its name from other speech acts which function similarly to it. The third type is called Superior speech act; it performs functions that other subordinate (inferior) speech acts perform as well. The study also identified three different types of utterances that perform speech acts; they are (1) Single Utterances, it performs a single speech act only; (2) Doubleedged utterances, it performs two speech acts concurrently; and (3) Falautterance, it performs three speech acts together. As for IFIDS, the study found out that there are several established concepts which helped in identifying speech acts in the interactions. The study recommends that research be carried out on other genres of interactive discourse such as long interviews, chat-shows, and written internet chat.

Emir and Raffir (2018) undertook a study on English speech acts of illocutionary force. The study aimed at gaining a deep understanding of illocutionary speech act. The researchers recorded two hundred and twenty (220) interactional events participated by lecturers and students. Qualitative descriptive approach was employed to analyse the data collected. The analysis reveals that lecturers participated in 160 interactional events while students participated in 90 interactional events. Lecturers dominated $59.09 \%$ of the interactional events while students dominated $40.91 \%$ of the interaction events. $21.569 \%$ of the interactional events were not properly carried out because Grice's Maxims of cooperative principles such as Maxim of quality and Maxim of manner were not observed. The illocutionary speech acts of directive were more dominant in the interactions, followed by representative / assertive illocutionary speech acts. The research further reveals that lecturers interrupted the interactions several times; and they did not provide opportunity for the students to talk after the interruptions. Besides, some students did not contribute to the talks in the class at all. The study concludes that the illocutionary speech act 
of directive has the higher social status than the illocutionary speech act of representative/assertive. The use of illocutionary force was highly related to the contexts of situation and culture of the speakers.

Wulandari (2014) carried out a research on speech act analysis of Facebook statuses used by the students of Muhammadiyah University of Surakarta. The aims of the study were to identify the types of speech acts used on Facebook statuses and describe their functions. The researcher read the Facebook statuses of class "A" members; classified them; copied all of them in English and coded them. He employed qualitative descriptive approach to analyse the data. The result of the analysis revealed that five different types of speech acts were found in the facebook. 53 data or $33.13 \%$ of the data were representative speech acts; 34 data or $21.25 \%$ of the data were directive speech acts; 8 data or $5.00 \%$ of the data were commissive speech acts; 64 data or $40.00 \%$ of the data were expressive speech act. The dominant speech acts in the Facebook statuses were expressive speech acts. The study further indicates that the speech acts performed 30 different functions on the Facebook statuses. The 30 functions the speech acts performed are as follows: (1) Representative speech act performs the function of describing, denying, persuading, asserting, informing; (2) Directive speech act does the function of directing, commanding asking;(3) commissive speech act performs the function of promising, pledges, vows; (4) Expressive speech act performs the function of thanksgiving, congratulations, confessing, appreciating, disappointing, dislike, hoping, satisfying, scaring, supporting, yearning, complaining, satisfying, boring, tiredness, confusing, apologizing sorrowful feeling ;(5) Declarative speech act performs the function of declaring. The study concludes that five types of speech acts were used on the Facebook statuses employed by the students of Muhammadiyah University of Surakarta; they performed 30 different types of functions.

From the above reviewed work, we notice that the researchers were preoccupied with the data collected from naturally occurring conversations on video tape, audio recording devices and YouTube. However, this particular study focuses on speech acts Analysis of dialogues in a literary text entitled This Is Our Chance.

\section{Theoretical Framework}

Speech act theory of J. L. Austin which was later developed by J.R. Searle is adopted as theoretical framework. Austin (as cited in Kempson, 1979) observes that to utter a sentence, the speaker is engages in three different acts, namely, locutionary act, illocutionary act and perlocutionary act. He further points out that locutionary act dwells on uttering a meaningful sentence; illocutionary act is concerned with what the speaker intends his utterance to convey, to promise, to praise, to criticize, etc, while perlocutionary act deals with the effect of the speaker's utterance on the listener or addressee.

Searle (as cited in Sharndama, 2015) classified speech acts into five namely: Directives, Representative, Expressive, Declaration and Commissives.

3.1. Directives

Black (as cited in Sharndama, 2015) explains that directives are speech acts employed by speakers to make their listener engage in certain activity. Directives involve order, command, directives, requests, suggestions, challenges, begging, asking, advice, and warning.

3.2. Representatives

Black (as cited in Sharndama, 2015) asserts that representatives are speech acts in form of statements and description. Interlocutors use these speech acts to give their opinions about the world and to describe how they understand it. Examples of representatives are assertion, reports, statements, descriptions, denying.

3.3. Expressives

Black (as cited in Sharndama, 2015) discloses that expressive speech acts reveal the speaker's state of mind and how he reacts to a situation, e.g. apologies, condoling, thanksgiving, congratulations, confessing, denying, complaints, appreciating, regretting.

3.4. Declaration

Ayodabo (2015) points out that declarations are speech act in which speaker utter words that changes the state of affair of the world of someone, e.g a judge can say to a person convicted, you are sentenced to death. This utterance will definitely change the world of the person convicted.

3.5. Commissives

Ayodabo (2015) says that commissive speech acts are the speech acts the interlocutors employ to commit themselves to future action, e.g. intent, threats, promises, pledges, and vows.

\section{Methodology}

Data for the study comprise of utterances randomly selected from the text under review. Dialogues in This Is Our Chance are identified and analysed based on speech act theory of J. L. Austin which was later developed by J. R. Searle.

4.1. Data Analysis and Interpretation

The text This Is Our Chance by Henshaw is characterized by a lot of dialogues classified into different speech acts.

\section{Directive Speech Act}

Directive speech act used in the text are command, request, directive, advice, asking question and warning. 


\section{Data No. 1}

\section{Commands}

Commands run throughout the text, examples:

Damba: “... I command you speak ...” p.16

Damba: "Stop ..." p.16

Ajugo: “..say it ...” p.18

Ajugo: "Bring him in ... p.20

Damba: "Shut up! .... p.20

Damba: "Stop, fool! ..." p.22

Damba: “... send this creature back to prison ..." p.22

Damba: “...Gather the harvest immediately ...” p.22

Damba: "Sit down ..." p.23

Damba: "Go on, Ajugo," p.26

Ajugo: "Stop, man ..." p. 27

Enusi: “...Spare this man...” p.28

Damba: “Stop, woman, stop! ..." p.30

Damba: "Hold your tongue; ..." p.30

Damba: "Go on Ajugo, go on, say it all ..." p.34

Ajugo: "Stop talking ..." p.36

Damba: "Rise Mboli's ambassador ..." p.38

Damba: "Leave this room ..." p.40

The speech acts are commands; their illocutionary acts are to make the addresses do what they are ordered to do. If the addressees obey the command, they will do what they are ordered to do.

\section{Data No. 2}

\section{Requests}

Requests are not prevalent in the text, examples:

Ayi: “...I beg you permit me to leave this village..." p.32

Bambulu: "I beg you to spare for me Ajugo's life ...." p.38

Bambulu: "Kneel down and thank the king." P.39

There is a sense of request here; if the addressees yield to the requests, they will grant them..

Data No. 3

\section{Directive}

Directives are not dominant in the text, examples:

Bambulu: "Do it for another week.." p.7

Damba: “...get your men, matchets, dogs and torches and search for them..." p. 19

Damba: "...call the rainmakers and tell them to send down a mighty downpour on Mboli's village”. p.22

Ansa: “... send a message to the wife of chief Mboli ..." p.23

Damba : "...disarm the men, call the women back from the farms..." p.38

Damba: “...bring out the children, gather the drums and instruments and let there be rejoicing..." p.39

The speech acts here are to direct; their perlocutionary effects might be to make the addressees do what they are directed to.

\section{Data No. 4}

\section{Advice}

Pieces of advice are widely given in the text, examples:

Damba: “Do not put your eyes into other people's frying pots ..." p.15

Enusi: "Your highness, these young people have not married. We can therefore return this boy to his father in exchange for your daughter." p. 25

Enusi: "Your Grace Return this boy to his father and get back your daughter ..." p.27

Enusi: "My Lord, ... spare this man in spite of all this hateful past. Let us look to the future." P.27

Enusi: "My Lord, ... Tradition or no tradition spare this man. Let him return this moment to his father, so that your daughter may be sent back to us. She is young, intelligent and educated ..." p.29

Ayi: "Listen to that Damba, ..." p.32

The illocutionary acts here are to advise; their perlocutionary effects might be to make the addressees abide by the pieces of advice given to them.

\section{Data No. 5}

\section{Questions}

Questions are components of directive speech act ; they are used through out the text, examples:

Ayi: "Madam, don't you know that people of Udura are our enemies?" p.5

Ayi: "What is it, madam?" p.5

Bambulu: "When will your father dispose this so-called, er...fortune teller?” P.9 
Damba: "Now may I ask who is this man called Vitamins?" p.9

Damba: “... what of the chief of the village of Udura, who has never heard of them?" p.10

Damba: "If men do not respect tradition how can society stand?" p.15

Damba: "... Enusi, have you ever seen a river which had not a source?" p.15

Damba: "Has he been poisoning your mind with his foolish idea of friendship with people who are daily plotting to destroy us?" p.16

Ajugo: “... what news have you?" p.18

Damba: "What is it, fellow?" p.18

Damba: “... Do you call one who runs away with another man's daughter noble?” p.21

Ambassador: "... may I wait for message to my Lord?” p.21

Damba: "What do you know of tradition or custom?" p.22

Damba: "Why have you left your bed Ansa? ..." p.23

Damba: “... Why did you not send for me instead of coming along?” p.23

Damba: "Any more news from chief Mboli?" p.25

Damba: “... Has your friend school teacher in prison given you new ideas?” p.25

Damba: “...Do you know what peace means?” p.28

Ayi: "... Sir, where would principle be without men to observe them?" p.29

Ayi: "How, would you like your daughter killed and your wife dead?" p.30

Damba: “... Did not our forefathers say that trouble never blows a whistle?..." p.31

Bambulu: "... How is it that a great chief as you should be a prisoner in your kingdom?” p.36

Bambulu: "What, sir, is the composition of this poison which you want us to drink?" p.36

Damba: "My child, are you alive?" p.37

Ajugo: “... Must I kneel and praise him because he has reluctantly spared my life?...” p.39

The illocutionary acts here are to ask; their perlocutionary effects might be to make the addressees supply the interrogators with information.

\section{Data No. 6}

\section{Warnings}

Warning are used scantly in the text, examples:

Kudaro: "... Father must never hear of it..." p.5

Kudaro: “... But please, do not tell anybody”. p.6

Damba: I warn you against making yourself impertinent before me..." p.16

The speech acts are to warn, the illocutionary acts are for the addressees to heed the warnings; the perlocutionary speech acts might be to frighten them not to do what they are warned not to do.

\section{Data No. 7}

\section{Statements}

Statements are elements of representative speech act; they are used extensively in the text, examples:

Bambulu: "This is the child of my brain, the product of my endeavor, and the materialization of my inventive genius ..." p.7

Bambulu: “... it is not your fault or mine that you do not understand the Queen's English...” p.8

Fortune-teller: "A mighty wind shall blow, a great rain shall fall, much harm shall be done ...” p.8

Bambulu:"... Your Grace, if the old lady fell into a pit and broke her neck, death in that case would not be due to Vitamins ...” p.11

Damba: "There is Education for you! No idea of Tradition and Village pride, no respect for customs ..." p.17

Damba: "My poor wife is ill with all this troublee, and I am sure that she will not be able to get up for a month ...” p.23

Damba: “... Mboli, your chief, is a figurehead. But I am a chief...” p.23

Damba: "... he scorns our traditional way of dancing where men and women dance, round in circles or lines, and

introduces a most shocking idea which he calls ballroom dancing ...." p.24

Enusi: “... Your Grace. There is many a future built on an insignificant past...” p.28

Ajugo: "Any marriage outside this village is punishable by banishment and in case of royalty, death ...” p.34

Ajugo: "I have sacrificed all I have for this village." p.36

Ajugo: "I have borne the brunt of all the suffering whilst performing the duties entrusted to me by tradition." p.39

Damba: "To the inexperienced such as you are, Enusi, everything is either too difficult or too easy..." p.28

Bambulu: "When your prophet talked of rain and storm, my lord, I did not believe him, but I see now that there was veracity in his prophesy ..." p.36

The illocutionary acts here are to inform; the perlocutionary effects might be to make the addressees be aware of current situations of things.

Data No. 8

\section{Reports}

Reports are components of representative speech act; they are prevalent in the text, examples:

Ajugo: “... a young man from this village has actually been secretly married to a girl from Udura ...” p.14 
Hunter:“... your daughter Kudaro, your Grace, your own royal daughter, has run away. This very afternoon I saw her with the son of the chief of Udura, who also must have run away from his own village ..." p.18

Ambassador: "Your Grace, the chief of Udura lets you know that your daughter was caught by our men whilst eloping with our prince ..." p.21

Ajugo: “... Your Highness, we have not recovered your daughter. But the misguided prince ... is here, safely placed where all misguided people go ...” p.19

Ajugo: "... Our men have caught the son of the chief of Udura, who at this moment is panting in your prison, and will presently be brought before you." P.19

Ajugo: ".... Our men are still searching for your daughter, and I have no doubt that before long they will bring her back too. ” p.19-20

Enusi: "Your daughter was thrown into prison as soon as she was caught by chief Mboli's men. But soon afterwards the Queen of Udura visited her and has since been very kind to her much to chief "Mboli's displeasure ..." p.25

Ambassador: "... yesterday the younger son of my chief lay in agony, stung by a venomous snake. Nothing we did could revive him ... your illustrious daughter saw him from the window of her prison. With much difficulty she persuaded us to free her for a moment. She brought out a small bottle which she said was given to her by her school teacher. She immediately tied a string of palm leaves above the bite and rubbed this medicine strenuously into the bite... There he lay, almost breathless and silent ... he heaved a sigh and then fell asleep. Two hours later he recovered and has since been perfectly well..." p.37

The illocutionary acts here are to report; the perlocutionary effects might be to make the addressees be aware of the things that happened.

Expressive speech act

The components of expressive speech acts used in the text are complaints and appreciations.

Data No. 9

\section{Complaints}

Examples of complaints used in the text are as follows:

Kudaro:"You have never told me that I am beautiful." p.3

Kudaro:"I hate this place. O heavens! It's dull, dull. Take me back to any big town by the seaside." p.4

Kudaro:“... I cannot be locked up in this forest for years, calling myself a Queen or whatever you like ... it's dull, dull, dull!” p.4

Kudaro:"Why has he taken me away from the school in town, where I was doing so well, and brought me back to this village?" p.4

Kudaro:"We will all get old if we don't die of boredom. There is no need for him to make anybody unhappy because it is his turn to get old”. p.5

Kudaro:"... Half the day I don't know what he is talking about. I always feel like breaking his head with an axe when he uses those big words; Queen's English he calls it.” p.6

Kudaro:“Whatever my father thinks of him is his own business. I don't care I don't like his teaching.” p.6

Kudaro:"... He promised to marry me. But how can he marry me when I am locked up in this village”? p.6

Damba:"There he goes, talking to himself again. Do you realise how much I want to hang you each time you begin talking that way?" p.17

The Illocutionary speech acts here are to complain, their perlocutionary effects might be to make the addressees be aware of what bother the speakers.

\section{Data No. 10}

\section{Appreciations}

Appreciations are used scantly in the text, examples:

Damba: "Good Ajugo ... my most worthy servant." p.20

Damba: "You speak well, Enusi ..” p.25

Damba: “Well spoken, child.” p.33

Enusi: "My Lord, I am overwhelmed." p.38

The illocutionary acts here are to appreciate; their perlocutionary effects might be to make the addressees feel that their speeches and/or deeds are appreciated.

\section{Data No. 11}

Declarations

Declarations are used scantly in the text, examples:

Ajugo: “... Damba, you must die” p.34

Damba: “... You shall die for your wickedness ...” p.38

The illocutionary acts here are to declare; the perlocutionary effect might be immediate change in the state of affairs of the addressees.

\section{Data No. 12}

Promise

Promise is an element of commissive speech act; it is not prevalent in the text, examples: 
Ayi: "I shall tell no one, madam".p.6

Damba: “... your people shall marry into our village as they like. And we shall advance as brothers enlightened and courageous ...”.p.38

Enusi: "I must follow you, sir ..." p.25

The illocutionary acts here are promises; their perlocutionary effects might be to make the addressees believe that the speakers will keep their promises

\section{Findings}

The researcher noticed that speech acts such as Directives, Representatives, Expressives, Declarations and Commissives are used in the text. Components of directive speech act such as questions and commands are prevalent in the text while those like pieces of advice, directives, warnings and requests are sparsely spread over the text; constituents of representative speech act such as statements and reports run throughout the text; elements of expressive speech acts like complaints and appreciations; part of commissive speech act such as promise, and declaration speech act are used scantly in the text.

\section{Conclusion}

The study discloses that dialogues used in the text are on the animosity between the people of Koloro and Udura villages on one hand and the efforts made by chief Damba and chief Mboli to maintain their traditions in their respective domains on the other hand. The research concludes that dialogues in the text constitute different types of speech acts that communicate a variety of information.

\section{References}

Ayodabo,J. O. (2015). Pragmatics of English as a Second Vernacular Language in Nigeria. In Ayodabo, J. O. and Butari, N. $\mathrm{U}$ (eds) Issues in Language and Linguistics. 3, Ilorin: Haybee press and publishing Co. Nig Ltd.

Al-Owaidi, M (2018) Investigating Speech Act in English and Arabic Short News Interviews: A Cross-cultural Pragmatic Study (Doctoral dissertation, University of Huddersfield). Retrieved from eprints. hud .ac. uk/id/eprint/34754/

Emir, B and Raffir, Z (2018) English Speech Acts of llocutionary Forces in Class Interaction .Retrieved from https://files.ericed.gov/fultext/Eju85917.pdf

EncyclopediaBritannica. Retrieved from https://www.britannica.com/biographt/James-Ene-Henshaw

Fadhil, A (2018). A Pragmatic Study of Speech Acts in School Speeches. Retrieved from https://www.reseachgate.net/publication/327230905-A-Pragmatic- study-of - speech- acts-in -school -speeches

Henshaw, J. E. (2004).This Is Our Chance ( $2^{\text {nd }}$ ed.) Ibadan, Nigeria: Bounty Press Ltd.

How to Do Things with Words-Summary. Retrieved from https:/www.erotes.com/topics/how-to-do-things-withwords/summary-837545.

Ian, K. (2020) Strengths and Weaknesses of Speech Acts. Retrieved from ukh.edu.vn/vi-vn/chi-tiet-tim/id/1917/strengthsand-weaknesses-of-speech-acts-2020.

Kempson, R. C. (1979) SemanticTheory. London, England: CUP..

Nordquist, R. (2020) Speech Act Theory. Retrieved fromhttps://www.thoughtco.com/speech-act-theory-1691986

Searle, J. R., Kiefer, F., \&Bierwisch, M. (Eds.).(1980). Speech Act Theory and Pragmatics Retrieved from https://link.springer.com/content/pdf/bfm\%/3A978-94-009-8964-\%2F1.pdf. $d$ Literary Studies, 9(3),.

Sharndama, E. C.(2015). Pragmatics of Political Discourse: A Speech Act Analysis of the Manifesto of the People's Democratic Party. In Ayodabo, J. O. and Butari, N. U. (eds) Issues in Language and Linguistics, Vol.3, Ilorin: Haybee Press and Publishing C. Nig. Ltd.

Traum, D. R. (1999). Speech Acts for Dialogue Agents. In Foundations of Rational Agency (pp. 169-201).Springer, Dordrecht. Retrieved from helios.parisdescartes.fr/-moraitis/webpapers/speechActs-Dialogues.pdf

Wulandari, S. (2014). Speech act analysis of facebook statuses used by students of Muhammadiyah University of Surakarta. (Doctoral dissertation, University of Muhammadiyah Surakarta). Retrieved from eprint. ums.acid/30110/12/NASKAH-PUBLICASI 